\title{
Contributions to the Turkish Aphid Fauna from Aegean and Mediterranean Part of Turkey
}

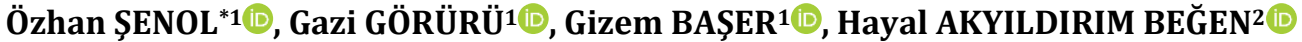 \\ ${ }^{1}$ Niğde Omer Halisdemir University, Arts and Science Faculty, Department of Biotechnology, 51100, Niğde, \\ Turkey \\ ${ }^{2}$ Artvin Coruh University, Health Services Vocational School, 08100, Artvin, Turkey
}

(Alınış / Received: 01.05.2021, Kabul / Accepted: 23.06.2021, Online Yayınlanma / Published Online: 25.12.2021)

\section{Keywords}

Aegean and Mediterranean Part,

Aphid,

Hemiptera,

Turkey

\begin{abstract}
The study conducted in Antalya and Muğla provinces from March to June, 2020. Aphis (Aphis) cirsiioleracei (Börner, 1932), Aphis (Aphis) coronillae Ferrari 1872, Aphis (Aphis) multiflorae Barbagallo \& Stroyan 1982, Aphis (Aphis) polygonacea, Matsumura 1917, Aphis (Aphis) sogdiana Nevsky 1929, Dasyaphis mirabilis (Tseng \& Tao 1938), Hyperomyzus (Hyperomyzus) carduellinus (Theobald 1915), Rhopalosiphum padiformis Richards 1962, Toxopterina vandergooti (Börner 1933), Sinochaitophorus maoi Takahashi 1936, Sipha (Rungsia) taurica, Mamontova 1959, Sipha (Rungsia) burakowskii Holman \& Szelegiewicz 1974, Sitobion (Sitobion) kamtshaticum (Mordvilko 1919), were recorded as new entry for Turkey aphid fauna. This study aimed to give detailed information about thirteen new entries for Turkey aphid fauna.
\end{abstract}

\section{Türkiye'nin Ege ve Akdeniz Bölgesinden Türkiye Afit (Hemiptera: Aphidoidae) Faunasına Katkılar}

\section{Anahtar Kelimeler}

Ege ve Akdeniz Bölgesi,

Afit,

Hemiptera,

Türkiye

\begin{abstract}
Özet: Çalışma 2020 yılı Mart ile Haziran ayları arasında Antalya ve Muğla illerinde gerçekleştirilmiştir. Aphis (Aphis) cirsiioleracei (Börner, 1932), Aphis (Aphis) coronillae Ferrari 1872, Aphis (Aphis) multiflorae Barbagallo \& Stroyan 1982, Aphis (Aphis) polygonacea, Matsumura 1917, Aphis (Aphis) sogdiana Nevsky 1929, Dasyaphis mirabilis (Tseng \& Tao 1938), Hyperomyzus (Hyperomyzus) carduellinus (Theobald 1915), Rhopalosiphum padiformis Richards 1962, Toxopterina vandergooti (Börner 1933), Sinochaitophorus maoi Takahashi 1936, Sipha (Rungsia) taurica, Mamontova 1959, Sipha (Rungsia) burakowskii Holman \& Szelegiewicz 1974, Sitobion (Sitobion) kamtshaticum (Mordvilko 1919)'un Türkiye afit faunası için yeni kayıt olarak belirlendi. Bu çalışmayla Türkiye afit faunası için yeni kayıt olan on üç yeni türle ilgili detaylı bilgi aktarmak hedeflenmektedir.
\end{abstract}

\section{Introduction}

In the beginning of the 19th century, the primary study about Turkey aphid fauna started. Studies on the aphid fauna of our country have started to increase relatively since the 1950s and the distribution, locality and host plants information of aphid species, has been started to present by both foreign researchers and Turkish researchers [1], [2]. First detailed study about Turkey aphid fauna was conducted by Görür et al. [3] and with this study 464 species and 12 subspecies listed. Since 2012 the studies about Turkey aphid fauna gradually increased and recently with contributions of various researchers Turkey aphid fauna reached to nearly 585 species [3], [4], [5], [6], [7], [8], [9], [10]. When we considered Turkey geographic features and climatic variations, it is expected that Turkey aphid diversity has to be richer than current findings, so there is need to be more detailed researches from different part of Turkey.

\section{Material and Method}

The study conducted in Antalya, Muğla and Karaman provinces from March to June 2020. Samples identified with Olympus BX51 microscope according to Blackman \& Eastop [11] and current species status checked by Favret [12]. To describe new aphid entry for Turkey aphid fauna BL (body length), BW (body weight), PT ( $5^{\text {th }}$ or $6^{\text {th }}$ antennal segment processus terminalis), BASE ( $5^{\text {th }}$ or $6^{\text {th }}$ antennal segment base), SIPH L (siphinculi length), SIPH W (siphinculi weight), RIV+V (ultimate rostral segments), HT II 
(Hind tarsus II), ANT III ( $3^{\text {rd }}$ antennal segment) used as distinctive morphometric characters. The voucher samples were stored at the Biotechnology Department of Nigde Ömer Halisdemir University.

\section{Results}

\section{Aphis (Aphis) cirsiioleracei}

Antalya/Manavgat; 31.V.2020

Wax dusted black aptera individuals were feeding shoot of Cirsium sp.. The populations were densely ant attended. ANT 5 segmented. They have black siphunculi and cauda that with 6 hairs. B.L. $1.10 \mathrm{~mm}$. PT/BASE $(0,19 \mathrm{~mm} / 0,07 \mathrm{~mm}) 2.71$.

\section{Aphis (Aphis) coronillae}

Muğla/Fethiye; 15.III.2020

Black aptera individuals were feeding on undersides of leaves of Medicago sp. The dorsal abdomen of individuals with extensive dark sclerosation, divided into polygons. BL. $1.78 \mathrm{~mm}$. PT/BASE (22/12) 1.83; SIPH L/Cauda (0.46 mm/0.22 mm) 2.09; SIPH L/BL (0.46 mm/1.78 mm) 0.25; SIPH L/ANT III $(0.46$ $\mathrm{mm} / 0.35 \mathrm{~mm}$ ) 1.3. Longest hairs on ANTIII $12 \mu \mathrm{m}$.

\section{Aphis (Aphis) multiflorae}

Antalya/it is on the way to between Manavgat and Akseki; Antalya/Manavgat 30.V.2020

Small yellowish black aptera individuals were feeding on leaf nodes of Erica bocquetti. They have uniformly dark siphunculi. BL $0.95 \mathrm{~mm}$. PT/BASE $(0.09$ $\mathrm{mm} / 0.05 \mathrm{~mm}$ ) 1.8; SIPH L/Cauda (0.08 mm/0.11 $\mathrm{mm})$ 0.72; RIV+V/HTII (0.09 mm/0.08 mm) 1.12 .

\section{Aphis (Aphis) polygonacea}

Antalya/Kaş-Ovaköy 2.VI.2020

Yellow aptera individuals were feeding on stem and undersides of leaves of Polygonum convolvus. The individuals have black cauda and siphinculi. BL. 1.80 mm. PT/BASE $(0.40 \mathrm{~mm} / 0.10 \mathrm{~mm}) 4$; SIPH L/Cauda (0.55 mm/0.25 mm) 2.2; RIV+V/HTII (0.15 mm/0.11 $\mathrm{mm}) 1.36$.

\section{Aphis (Aphis) sogdiana}

Antalya/Manavgat 31.V.2020

Small pale green aptera individuals were feeding on undersides of leaves of Ulmus sp. BL. $1.40 \mathrm{~mm}$. PT/BASE (0.16 mm/0.07 mm) 2.28; SIPH L/Cauda $(0.14 \mathrm{~mm} / 0.17 \mathrm{~mm}) \quad 0.82 ; \quad \mathrm{RIV}+\mathrm{V} / \mathrm{HTII}(0.09$ $\mathrm{mm} / 0.07 \mathrm{~mm}) 1.28$.

\section{Dasyaphis mirabilis}

Antalya/Serik-Uçansu waterfall 30.V.2020

Small yellow aptera individuals were feeding on undersides of leaves of Juglans sp. Antenna 3 segmented. BL $1.15 \mathrm{~mm}$.

\section{Hyperomyzus (Hyperomyzus) carduellinus}

Muğla/Yatağan and Gülağzı 13.III.2020; Antalya/Alanya 16.III.2020; Antalya/Döşemealtı 01.VI.2020

Green aptera individuals were feeding on receptacle of Sonchus sp. BL $2.28 \mathrm{~mm}$. ANTIII has 20 secondary rhinaria, ANTIV and ANT $\mathrm{V}$ have 0 secondary rhinaria. PT/BASE $(0.63 \mathrm{~mm} / 0.14 \mathrm{~mm}) \quad 4.5$; PT/Cauda (0.63 mm/0.27 mm) 2.33 .

\section{Rhopalosiphum padiformis}

Antalya/Kumluca-Kargılı picnic site 01.VI.2020

Dark green aptera individuals were feeding on curved leaves of Arundo sp. BL. $1.70 \mathrm{~mm}$. PT/BASE 0.38 $\mathrm{mm} / 0.09 \mathrm{~mm})$ 4.22; SIPH L/Cauda $(0.26 \mathrm{~mm} / 0.12$ $\mathrm{mm})$ 2.16; SIPH L/SIPH W (0.26 mm/0.08 mm) 3.25; SIPH L/BL (0.26 mm/1.70 mm) 0.15; RIV+V/HTII $(0.12 \mathrm{~mm} / 0.10 \mathrm{~mm}) 1.2$.

\section{Toxopterina vandergooti}

Muğla/Akbük 14.III.2020

Green aptera individuals were feeding on receptacle of Anthemis sp. BL $1.50 \mathrm{~mm}$. PT/BASE $(0.47 \mathrm{~mm} / 0.10$ $\mathrm{mm}$ ) 4.7; SIPH L/Cauda (20 mm/11 mm) 1.8. RIV+V $0.12 \mathrm{~mm}$.

\section{Sinochaitophorus maoi}

Antalya/Alanya-Alara 30.V.2020; Antalya/Manavgat 31.V.2020

Small green aptera individuals were feeding on undersides of leaves of Ulmus sp. and densely ant attended. Cauda knobbed, siphunculi short truncate cones and anal plate bilobed. BL. $1.15 \mathrm{~mm}$. SIPH L/SIPH W (0.07 mm/0.05 mm) 1.4; PT/BASE $(0.07$ $\mathrm{mm} / 0.09 \mathrm{~mm})$ 0.77; RIV+V/HTII (0.09 mm/0.09 mm) 1; ANT III $0.22 \mathrm{~mm}$.

\section{Sipha (Rungsia) burakowskii}

Antalya/Akdeniz University Campus area 01.VI.2020

Black aptera individuals were feeding on leaf stalks of Hordeum sp. and ant attended. BL. $1.50 \mathrm{~mm}$. PT/BASE (0.07 mm/0.07 mm) 1; RIV+V/HTII $(0.08 \mathrm{~mm} / 0.10$ $\mathrm{mm})$ 0.8; BL/BW (1.50 mm/0.64 mm) 2.34. 


\section{Sipha (Rungsia) taurica}

Antalya/ it is on the way to between Serik and Köprülü canyon 31.V.2020

Yellow aptera individuals were feeding on undersides of leaves of Cynodon sp. ANT 5 segmented. BL. 1.10 mm. PT/BASE (0.08 mm/0.06 mm) 1.33; BL/BW $(1.10 \mathrm{~mm} / 0.45 \mathrm{~mm}) \quad 2.44 ; \quad \mathrm{RIV}+\mathrm{V} / \mathrm{HTII} \quad(0.08$ $\mathrm{mm} / 0.12 \mathrm{~mm}) 0.66$.

\section{Sitobion (Sitobion) kamtshaticum}

Antalya/ it is on the way to between Manavgat and Akseki 30.V.2020

Orange aptera individuals were feeding on spica of Triticum sp. ANT III bears one secondary rhinaria. Antenna and siphinculi black, cauda pale and tibia pale, but black distally. BL. $1.70 \mathrm{~mm}$. PT/BASE $(0.70$ $\mathrm{mm} / 0.11 \mathrm{~mm})$ 6.36; SIPH L/Cauda $(0.47 \mathrm{~mm} / 0.30$ $\mathrm{mm})$ 1.56; SIPH L/BL (0.47 mm/1.70 mm) 0.27; $\mathrm{RIV}+\mathrm{V} / \mathrm{HTII}(0.12 \mathrm{~mm} / 0.14 \mathrm{~mm}) 0.85$. Longest hairs of ANTIII is $20 \mu \mathrm{m}$.

\section{Discussion and Conclusion}

Up to date approximately 585 aphid species determined from Turkey. Currently Şenol et al. [13] added Acyrthosiphon (Acyrthosiphon) papaverisuctum (Zhang, Chen, Zhong \& Li, 1999), Aphis (Aphis) aquilonalis Stekolshchikov \& Khruleva, 2015, Brachyunguis (Brachyunguis) tamaricophilus (Nevsky,1928), Diuraphis (Diuraphis) muehlei (Börner,1950), Melanaphis elisabethae (Ossiannilsson, 1967), Metopolophium (Metopolophium) chandrani (David \& Narayanan, 1968), Paczoskia meridionalis Holman, 1981, Paracletus donisthorpei Theobald, 1929, Sitobion (Sitobion) rosaiformis (Das, 1918), Uroleucon (Uroleucon) murale (Buckton, 1876) from south eastern part of Turkey. The genus Dasyaphis Takahashi, 1918 and Sinochaitophorus Takahashi, 1936 also new genus entry for Turkey aphid fauna. The genus Dasyaphis includes two species as D.mirabilis and D.rhusae, which are oriental orginated. The genus Sinochaitophorus includes one species (S.maoi), which recorded from Siberia, Mangolia and China. With this study 13 aphid species determined as new records for Turkey aphid fauna and Turkish aphid fauna reached to nearly 598 aphid species. When we evaluate geographical and climatic features of Antalya, Muğla and Karaman, these findings were preliminary results of our project and it is expected that the more new entries will determine from study area.

\section{Acknowledgment}

The authors thank to the Scientific and Technological Research Council of Turkey (TUBITAK; Project Number 119Z250).

\section{Declaration of Ethical Code}

In this study, we undertake that all the rules required to be followed within the scope of the "Higher Education Institutions Scientific Research and Publication Ethics Directive" are complied with, and that none of the actions stated under the heading "Actions Against Scientific Research and Publication Ethics" are not carried out.

\section{References}

[1] Tuatay, N., Remaudiere, G. 1964. Première contribution au catalogue des Aphididae (Hom.) de la Turquie. Revue de Pathologie Végétale et d'Entomologie Agricole de France, 43(4), 243278.

[2] Çanakçıŏlu, H. 1975. The Aphidoidea of Turkey. University of İstanbul Forestry Faculty Press, İstanbul, 309 pp.

[3] Görür, G., Akyıldırım, H., Olcabey, G., Akyürek, B. 2012. The aphid fauna of Turkey: An updated checklist. Archives of Biological Science Belgrade, 64(2), 675-692.

[4] Remaudière, G., Toros, S., Özdemir, I. 2006. New contribution to the aphid fauna of Turkey (Hemiptera, Aphidoidea). Revue française d'Entomologie, 28(2), 75-96.

[5] Görür, G., Şenol, Ö., Akyıldırım Beğen, H. 2019. Adıyaman, Malatya ve Şanlıurfa İllerinden Belirlenen Afit Türlerinin Türkiye Afit Faunasına Katkıları Açısından Değerlendirilmesi. Selçuk Üniversitesi Fen Fakültesi Fen Dergisi, 45(2), 103-115.

[6] Görür, G., Şenol, Ö., Akyıldırım Beğen, H., Akyürek, B. 2020. Foresights derived from recent studies conducted on Turkey aphid fauna. Atatürk University Journal of Agricultural Faculty, 51(1), 63-68.

[7] Kök, Ş., Kasap, I. 2019. Aphid (Hemiptera: Aphididae) species of the South Marmara Region of Turkey including the first record of Dysaphis radicola meridialis Shaposhnikov, 1964 for the aphid fauna of Turkey. Turkish Journal of Entomology, 43(1), 63-78.

[8] Özdemir, I. 2020. Some New Records on Aphid (Hemiptera, Aphididae) Fauna of Turkey and Aphid Host Plant Interactions. Journal of the Entomological Research Society, 22(2), 191-201.

[9] Kök, Ş., Özdemir, I. 2021. Annotated Systematic Checklist of the Aphids (Hemiptera: Aphidomorpha) of Turkey. Zootaxa, 4925(1), 174.

[10] Blackman, R., Eastop, V. 2021. Aphids on the World's plants: An online identification and information guide. http://www.aphidsonworldsplants.info (Accession date: 28.05.2021). 
[11] Görür, G., Şenol, Ö., Akyıldırım Beğen, H., Akyürek, B. 2021. Turkish aphid. www.turkishaphid.com (Accession date: 01.07.2021).

[12] Favret, C. 2020. Aphid Species File. http://aphid.speciesfile.org (Accession date:
28.05.2021).

[13] Şenol, Ö., Görür, G., Beğen, H. A. 2019. Contributions of the Anatolian Diagonal effect on Turkish aphid diversity. Artvin Çoruh Üniversitesi Orman Fakültesi Dergisi, 20(1), 102-109. 